\title{
Integrated View of Inter-Firm Cooperation: An Empirical Study in Tourism Region
}

\author{
Nguyen Phuc Nguyen ${ }^{1}$ \\ ${ }^{1}$ University of Economics, The University of Danang, Danang City, Vietnam \\ Correspondence: Nguyen Phuc Nguyen, University of Economics, The University of Danang, Danang, 71 Ngu \\ Hanh Son, Danang City, Vietnam. Tel: 84-511-395-0475. E-mail: nguyennp@ due.edu.vn
}

Received: May 8, 2015

doi:10.5539/ijef.v7n8p77
Accepted: May 22, 2015

Online Published: July 25, 2015

URL: http://dx.doi.org/10.5539/ijef.v7n8p77

\begin{abstract}
Many studies have tried to explain the inter-firm relationship especially inter-firm cooperation. However, among them, the role of social influence has gotten little empirical investigation or to be neglected. Using survey data from SME tourism enterprises in Vietnam, the study tries to explain inter-firm behaviours based on integrating theories from different disciplines. The study reveals that cooperative intention is the main predictor of cooperative decision. Further, it confirms the positive influence of social impact and similarities between partners on inter-firm cooperation. The study provides theoretical and managerial foundations because the research addresses the relationships among these constructs in inter-firm context.
\end{abstract}

Keywords: cooperation, social influence, similarity, inter-firm relationship, theory of planned behaviour, Vietnam

\section{Introduction}

Inter-firm relationship especially inter-firm cooperation has been the main focus of interest among academics several years. Scholars have conducted various studies to explain the nature of inter-firm relationship (Anderson \& Narus, 1990; Close \& Kukar-Kinney, 2010; Kennedy et al., 2001; Morgan \& Hunt, 1994; Nguyen \& Rose, 2009; Nguyen, 2011). They revealed the antecedents of this relationship such as trust or commitment. However, for the author's knowledge, empirical study about the impact of social influence or manager's characteristics is scare.

On the other hand, the theory of reasoned action (TRA) (Fishbein \& Ajzen, 1975) and its extended model (TBP-Ajzen, 1991) are those models to explain human behaviour including cooperative one. Moreover, technology acceptance model (TAM) (Davis, 1986; Davis et al., 1989) is an adaptation of TRA specifically tailored for modelling user acceptance of information systems. They mainly confirmed the role of intention in predicting behaviour (Ajzen, 1991; Corner \& McMillan, 1999; Hill et al., 1996; Netemeyer et al., 1993). It seems that we can apply these model in explaining the specific type of behaviour: inter-firm relationship.

Therefore, the study tries to explain inter-firm cooperation based on applying theories from various disciplines. Using SME tourism enterprises in Vietnam, the present research contributes not only for theoretical knowledge but also for practical implications. First, the study confirms the role of TPB in explaining human behaviour as well as firm behaviour. Second, the study enhances our knowledge about the impact of social influences on firm behaviour in transition economy. Third, the study suggests the way to facilitate inter-firm relationship.

The remainder of this paper is organized as follows. In the following section, the study highlights theoretical foundations regarding behaviours and its hypotheses. Then the study presents a discussion of the methods, data analyses and results. Finally, the study outlines the contribution of the study and the implications for research and practice.

\section{Background and Hypotheses}

There can be many reasons why a company intends to make cooperation with particular partner. Due to superior benefits from cooperative relationship, firm will commit itself into that relationship. Similarly, a firm may engage in cooperative relationship with particular partner because social pressures may enforce this relationship upon the firm. Finally, a company may feel good and safety for inter-firm cooperation based on the existence of control mechanism. On the other hand, inter-firm cooperation is as similar or complementary coordinated actions 
taken by firms in interdependent relationships to achieve mutual outcomes or singular outcomes with expected reciprocation over time (Anderson \& Narus, 1990). Empirical studies have shown the direct effect of behavioural intention on behaviour (Ajzen, 1991; Davis et al., 1989; Kumar et al., 2003). Further, the study also investigates the impact of firm and regional attributes on this type of inter-firm behaviour.

\subsection{Cooperative Intention}

An intention is self-assessment of the likelihood of engaging in a particular behaviour (Atkinson, 1964). According to the theory of reasoned action (Fishbein \& Ajzen, 1975) and its subsequent version (TPB) (Ajzen, 1991), the predictor of behaviour is person's intention. Similarity, Davis et al. (1989) postulate that behavioural intention is the major determinant of behaviour, and that any other factors that influence user behaviour do so indirectly by affecting behavioural intention. Furthermore, intention derives from one's desire to achieve positively valent outcomes or avoid negatively valent results (Deci \& Ryan, 1987). Therefore, the study defines cooperative intention as intention of a firm to build inter-firm cooperation with partners to achieve goals. It is a broad concept, which implies goals and plays multiple roles (cf. Nguyen, 2011, p. 64).

Many researchers have empirically proved that behavioural intention has close relationship with decision making (Armitage \& Conner, 2001; Netemeyer et al., 1993; Nysveen et al., 2005). In addition, Sheppard et al. (1988) report the average correlation of 0.53 between intentions and behaviour based on a meta-analysis of 87 studies. Recently, in the effort of examining the applicability of TPB in e-commerce context, De Cannière et al. (2009) indicate that intention does play an important role in fully mediating the impact of other constructs on behaviour. Further, they state that intention indeed predicts actual behaviour. No hypothesis is advanced, but the study expects that in high involvement behaviour like inter-firm cooperation, this component does lead to cooperative behaviour.

H1. Cooperative intention has positive relationship with cooperative decision and fully transmits the effects of all other antecedents.

\subsection{Expectation from Inter-Firm Cooperation}

The current literature on inter-firm relationships and technology acceptance highlights the importance of motivation for behaviour. They can be expectation of success (Bagozzi \& Warshaw, 1990), perceived usefulness (Davis, 1986), and relationship benefit (Morgan \& Hunt, 1994). Firm can engage in inter-firm relationship in order to achieve specific goals/rewards (Deci \& Ryan, 1987; Huybers \& Bennett, 2003; Nguyen, 2011) or perceived desirability (Krueger et al., 2000).

Generally, expectancy value theory stresses that behaviour is a joint function of people's expectations of obtaining particular outcomes. Schermerhorn (1975, p. 848) notes that firms find benefits associated with cooperation will commit themselves into that kind of relationship. Similarity, Lancastre and Lages (2006) suggest that relationships, which provide partners with superior economic benefits, will foster effective cooperation. Importantly, a customer will not develop an intention to build a relationship with particular firm if he/she receives no perceived value (Kumar et al., 2003). Nguyen (2011) finds that firms who expect much of relationship performance have higher probability of inter-firm cooperation. Equally, Bagozzi and Warshaw (1990) state that desires are sufficient motivators to start behavioural intention when self-efficacy exists. In addition, Davis (1986) reveals the importance impact of perceived usefulness on behavioural intention. The expectation from inter-firm relationship can stimulate manager's intention to make cooperation with its partner even if they do not possess a positive attitude toward partner or partner's representatives (see Nysveen et al., 2005 for details). Thus,

H2. There is a positive relationship between expectation from inter-firm cooperation and cooperative intention.

\subsection{Attitude toward Inter-Firm Cooperation}

According to TRA and TPB, attitude toward behaviour is as an individual's positive or negative feelings about performing specific behaviour (Fishbein \& Ajzen 1975, p. 216). This element is a function of salient beliefs about consequences of performing behaviour and the evaluation of those results. Attitude toward behaviour is a key element in human behaviour. Scholars have highlighted the importance of this element in activating inter-firm behaviour (Hill et al., 1996; Kulviwat et al., 2009; Tonglet et al., 2004). A study of Carr and Sequeira (2007) in family business indeed shows that attitude towards starting a business partially mediates the main effects of family business experience on entrepreneurial intent. On the same fashion, Lui et al. (2006) state that trust provides basement for inter-firm cooperative formulation by fully mediating the relationship of firm similarity and partner reputation with coercive strategy. Besides, Bagozzi and Warshaw (1990) find that recently trial action will affect the formation of intention to try. 
On the other hand, literature on technology suggests that attitude is likely to shape behavioural intention (Davis et al., 1989; Koufaris, 2002; Nysveen et al., 2005). Furthermore, specific type of attitude: attitude toward advertising has shown its positive effect on customer's intention (Durvasula et al., 1993; Heikki et al., 2008). Thus, the study expects that manager's predisposition will have positive impact on cooperative intention.

H3. The higher attitude toward inter-firm cooperation placed in manager, the higher cooperative intention becomes.

\subsection{Subjective Norms}

According to Fishbein and Ajzen (1975), subjective norms are norms, which refer to external and interpersonal influence. This variable refers to doing what other people want one to do, and the motivation complies with important referents. This looks similar to injunctive norms (what others expect one to do) in Thøgersen (2008). Subjective norms have received much attention from various disciplines. The literature suggests a positive relationship between subjective norms and intended behaviour (Ajzen, 1991; Hill et al., 1996; Sheppard et al., 1988). Empirical works have shown that subjective norms influence behavioural intentions. Thøgersen (2008), for instance, discovers that two types of normative beliefs influence cooperation synergistically rather than additively. Similarity, Kulviwat et al. (2009) indicate that social influence has positive effect on consumer intention to adopt an innovation. Therefore, the study hypothesizes that:

H4. There is positive relationship between subjective norms and cooperative intention.

\subsection{Perceived Control}

Control concept is one of very important elements in studies of human behaviour. This concept has gotten many different names such as perceived behavioural control (Ajzen, 1991), self-efficacy (Bandura, 1997), and perceived control (Nysveen et al., 2005). Perceived behavioural control relates to people's perception of the ease or the difficulties of performing behaviours. According to Ajzen (1991, p. 184), this variable, together with behavioural intention, is useful for predicting behaviour.

There is a growing evidence to support the effect of perceived control and self-efficacy on behavioural intention. This element has received empirical supports from many studies (Hill et al., 1996; Neetemeyer et al., 1993; Tonglet et al., 2004). However, the effect of self-efficacy and perceived control on behavioural intention is typical not consistent across researches. For example, while Terry and O'Leary (1995) find that perceived behavioural control predicts exercise behaviour, Manstead and van Eekelen (1998) argue the positive role of self-efficacy on intention. Although there is mismatch between these researches, the study expects that:

H5. The perceived control has positive relationship with inter-firm cooperation.

\subsection{Similarities between Partners}

A company will not success in managing alliance if it does not understand its partner. The relatively similarity between partners reduce the incentives for free riding and enhances the possibility of inter-firm cooperation (Huyber \& Bennett, 2003). Similarities between partners can shape inter-firm relationship and cooperative behaviour because they can facilitate the articulated knowledge among firms (Teece, 1977; Saxton, 1997). In addition, it can help partners build inter-firm trust and inter-firm cooperation as the result. When firms are similarity in strategic decision and culture, they can get along with its partner. Moreover, similarities between partners lead to balanced inter-firm power relationship and impact to level of cooperation in the network-firm (Chassagnon, 2014). Therefore, we expect that:

H6: Similarities between partners will be positively related to cooperation intention.

\section{Method}

\subsection{Data}

The empirical data in this research consist of questionnaire responses from managers in SME tourism enterprises in Vietnam. The questionnaire firstly written in English was translated into Vietnamese. Due to their high level of knowledge about the firm and its cooperative activity, the target key informants are managers or owners. A pilot survey (with 50 responses) was conducted in May 2014 in order to refine the questionnaires and gain additional comments on the content and appearance. The constructs were revised based on their feedback to improve the format and scale measures.

Prior to mailing the questionnaires, each key informant was pre-contacted by telephone in order to obtain cooperation by stressing the importance of this study. The final version of questionnaire was mailed to the key informants in each firm with a postage-paid reply envelope. At the end with this process, the study ended up with 
a random sample of 600 firms and hotels in tourism region along the central coast of Vietnam. The survey was carried from July 2014 to September 2014. The initial follow-up telephone calls are made to non-respondents 4 weeks after the questionnaires were sent. Approximately 4 weeks after the first follow-up, non-respondents were telephoned, followed by a soft copy of the questionnaire and a handwritten postcard one week later as a reminder In total of 276 received questionnaires, 262 responses were validated for testing hypotheses. The detail of constructs are shown in the appendix.

\subsection{Measures}

\subsubsection{Dependent Variable}

Cooperative decision has been measured in many ways in previous studies. This variable can be measured by multiple items like Thøgersen (2008); Zhang and Wang (2014) or by single one in Ludin (2007), Pittino and Visintin (2011) and Chassagnon (2014). Following the instruction of Nguyen (2011) and Pittino and Visintin (2011), the study and uses dummy variable as a proxy to measure cooperation decision between firms in tourism region. A dichotomous variable that assumes value 1 if the enterprise has started one or more cooperation agreements at the time of the research or up to three years before and a value of zero otherwise.

\subsubsection{Independent Variables}

\section{- Expectation from inter-firm cooperation (Expectation)}

To measure expectation from inter-firm cooperation, the study has adapted and modified five items developed by Chow et al. (2012) and Venkatesh (2000) in order to fit organizational context. The study uses 7-point Likert scale for this measurement. This constructs displays high reliability, which is shown as Cronbach's alpha $(\alpha=0.87)$.

- Attitude toward inter-firm cooperation (Attitude)

Attitude toward behavior in general and attitude toward advertising specifically have been studied in widely literature such as Ajzen (1991), Durvasula et al. (1993). However, the items developed in these researches were found inappropriate for the purpose of present study because they are different from definition as well as field study. Therefore, the scale was developed based on the works of Fang et al. (2008), Lui et al. (2006), and Morgan and Hunt (1994). Four items are used to measure predisposition toward cooperation. The scale shows a high degree of internal consistency $(\alpha=0.88)$.

- $\quad$ Subjective norms (Subjective)

Thøgersen (2008) indicates that people hold both types of normative beliefs in order to cooperate. Hence, the construct of subjective norms in the study is assessed from two perspectives: injunctive norm and descriptive norm using three items. One of the injunctive norm measurements was adapted from Nguyen (2011). The study develops the remains on the foundations of Conner and McMillan (1999), and Okamuro (2007). Four items were used to investigate the effect of social factors on cooperative intention in general. Cronbach's alpha for the scale is 0.77 .

\section{- Perceived control (Perceived)}

This construct was evaluated based on four statements using 7-point Likert scale. One example of the statements is "Using legal systems (e.g. court, contract law) to require partner fulfill responsibilities for the project". Three other statements were developed based on studies of Ajzen (1991), and Conner and McMillan (1999). This measure displays good reliability $(\alpha=0.88)$.

- Similarities between partners (Similarities)

Similarity between partners is the essential feature of the inter-firm relationship. The similarity scale was based on six items that asked respondents to indicate the similarities between their and its partner on the range of organizational characteristics (Saxton, 1997). $(\alpha=0.90)$.

- Cooperative intention (Intention)

Three items, adapted from Nasco et al. (2008); Beritelli (2011) and Nguyen (2011), were used to measure cooperative intention of executive/owner. This construct presents adequate reliability $(\alpha=0.84)$.

\subsubsection{Control Variables}

The study adds two control variables to account for important variation among company characteristics and regional context. Sets of dummy variables are included to determine the size of company (small, medium, and large). This variable has demonstrated important role in inter-firm cooperation from empirical works of Arku 
(2002) and Fritsch (2003). Based on resources- base perspective, the study expects that size of firm has negative effect on inter-firm relationship. Due to lack of necessary resources or knowledge, smaller companies are eager for cooperation with other companies.

The second control variable relates to ownership. The dummy variables, which value 1 if firm is owned by specific subject (state, private or foreign owned) are added, respectively. Executives of particular type of ownership likely have different objectives and attitudes toward inter-firm relationship (Nguyen \& Rose, 2009).

\subsection{Empirical Model}

The study aims to test the impacts of determinants of inter-firm relationship on the level of cooperation of these relationships. The dependent variable Cooperation is dichotomous and it has its latent variable.

Let Cooperation $_{i}$ denote the decision of enterprise i whether or not to establish cooperation with its partner with the latent model is as follows:

$$
\text { Cooperation }_{i}=\beta_{0}+\beta \text { Intention }_{i}+\delta X_{i}+\varepsilon_{i}
$$

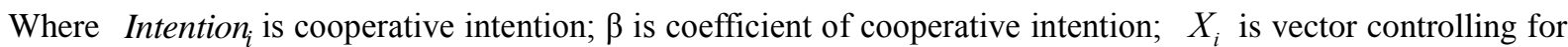
size and ownership; $\delta$ is vector of parameters of $X_{i}$ and $\varepsilon_{i}$ is the error term. According to Rivers and Vuong (1988), the study can obtain consistent estimates by using an instrumental variables (IV) probit model. Therefore, the instrument equation in this study is:

$$
\text { Intention }_{i}=\alpha+\varphi \text { Expectation }_{i}+\chi \text { Attitude }_{i}+\gamma \text { Subjective }_{i}+\kappa \text { Perceived }_{i}+\lambda \text { Similarities }_{i}+\eta X_{i}+\tau_{i}
$$

The study jointly estimates both equations (1) and (2) by maximum likelihood method.

\section{Results}

The study uses two-steps approach to test the proposed hypotheses. The confirmatory factor analysis (CFA) is introduced to test the construction validity of the questionnaire. Then the study uses the structural model approach (Cameron \& Trivedi, 2009), which allows simultaneous interaction among constructs, to test research hypotheses.

\subsection{Common Method Variance}

In order to assess the possibility of common method variance, the study adapts Harman's one-factor test (Podsakoff et al., 2003). The study enters all items into an exploratory factor analysis with principal axis factoring and orthogonal rotation. At the end of this process, the study use six factors account for $79.14 \%$ of the variance explained. No single factor is dominant. The first factor, which contributes most to the explained variance, only accounts for $21.46 \%$ of the variance. Therefore, common method variance does not exist in this study.

Potential non-response bias was assessed via extrapolation method of comparing early versus late respondents (Armstrong \& Overton, 1977). Firstly, a comparison of early to late responses revealed no difference with regard to the means of all variables, especially on company's age and size. Secondly, an analysis of ownership distribution of the respondents shows no difference from the ownership distribution of all the firms and hotels used in the survey. Therefore, the non-response bias was minimal.

\subsection{Discriminant Validity}

The study examines the convergent and discriminant validity of study's variables prior to hypothesis testing. The study conducts confirmatory factor analyses (CFA) by using LISREL 8.80 with the maximum likelihood method. Table 1 provides the results of the measurement analysis.

The chi-square for this model is significant $\left(\chi^{2}=597.62, d f=223, p<.001\right)$. Because chi-square statistic is sensitive to sample size (Chen et al., 2008), therefore the study uses the normed chi-square $\left(\chi^{2} /\right.$ degrees of freedom) as an alternative index. The normed chi-square in this study is below the recommended cutoff of 5.0 (Schumacker \& Lomax, 2004). The RMSEA of this model (0.071) meets the requirements of acceptable model (Hair et al., 2009). These indices indicate a good fit to the population. The result indicates that all constructs have adequate internal consistency with Cronbach's alpha ranging from 0.77 to 0.90 , ensuring adequate internal consistence of multiple items of each construct (Hair et al., 2009). 
Table 1. Convergent and discriminant validity in measurement model

\begin{tabular}{lccccccc}
\hline Constructs & $\mathbf{1}$ & $\mathbf{2}$ & $\mathbf{3}$ & $\mathbf{4}$ & $\mathbf{5}$ & $\mathbf{6}$ & $\mathbf{C R}$ \\
\hline 1. Expectation from inter-firm cooperation & 0.59 & & & & & & 0.88 \\
2. Attitude toward inter-firm cooperation & 0.38 & 0.70 & & & & & 0.90 \\
3. Subjective norms & 0.13 & 0.31 & 0.66 & & & 0.80 \\
4. Perceived control & 0.06 & 0.38 & 0.03 & 0.58 & & 0.85 \\
5. Similarities between partners & 0.20 & 0.30 & 0.10 & 0.03 & 0.64 & 0.91 \\
6. Cooperative intention & 0.48 & 0.62 & 0.34 & 0.12 & 0.25 & 0.63 & 0.84 \\
\hline
\end{tabular}

Note. The AVE's are on the diagonal, and the squared coefficients between construct are below the diagonal.

Based on suggestion of Hair et al. (2009), there are three ways to examine convergent validity. First, standardized loadings should be 0.5 and ideally 0.7 or higher. All item loadings, are near or above 0.7 and significant. Second, the average percentage of variance extracted (AVE) should be greater than 0.5 , suggesting adequate convergence (Fornell \& Larcker, 1981). All constructs in this research meet this requirement (see Table 1). Third, similar to Cronbach's alpha, construct reliability (CR) will be used to test reliability. Construct reliability is that 0.7 or higher suggests good reliability (Hair et al., 2009). The study also passes this test. Overall, these results suggest that the proposed model has good convergent validity. Furthermore, the study conducts discriminant validity test by comparing the AVE of each construct with the squared correlation coefficient between constructs. The AVEs are greater than the squared correlations between any pair of constructs, suggesting that this criterion is satisfactory (Fornell \& Larcker, 1981). All the constructs satisfy this test. Therefore, the result indicates good discriminant validity of the model.

\subsection{Regression Results and Test of Hypotheses}

Following Van Bruggen et al. (2002), the study adapts a confidence-based weighted mean to obtain construct scores. The single overall confidence score, which is standardized loading, applies for the type of weight. Appendix provides an overview of the variable means, standard deviation, and the correlation matrix among the variables. The study uses STATA 13 package for testing hypotheses by implementing instrument variable method, called IVprobit. The result is as Table 2.

Table 2. IVprobit regression results

\begin{tabular}{|c|c|c|c|c|c|c|}
\hline \multirow[b]{2}{*}{ Variables } & \multicolumn{2}{|c|}{ Case 1} & \multicolumn{2}{|c|}{ Case 2} & \multicolumn{2}{|c|}{ Case 3} \\
\hline & Cooperation & $\begin{array}{c}\text { Instru. equation } \\
\text { Intention } \\
\end{array}$ & Cooperation & $\begin{array}{c}\text { Instru. equation } \\
\text { Intention } \\
\end{array}$ & Cooperation & $\begin{array}{c}\text { Instru. equation } \\
\text { Intention } \\
\end{array}$ \\
\hline Constant & $-3.67 * * *$ & $0.72 * * *$ & $-4.19 * * *$ & $0.94 * *$ & $-4.84 * * *$ & $1.05^{* * *}$ \\
\hline Intention & $0.92 * * *$ & & $0.93 * * *$ & & $1.01 * * *$ & \\
\hline Expectation & & $0.56 * * *$ & & $0.60 * * *$ & & $0.62 * * *$ \\
\hline Attitude & & $0.37 * *$ & & $0.38 * * *$ & & $0.36^{* * *}$ \\
\hline Subjective & & $0.23 * *$ & & $0.25^{* *}$ & & $0.26^{* * * *}$ \\
\hline Perceived & & $0.28 * *$ & & $0.24 * *$ & & $0.30 * *$ \\
\hline Similarities & & $0.43^{* *}$ & & $0.44 * *$ & & $0.46^{* * *}$ \\
\hline Small & & & $0.89^{* * *}$ & $-0.23 *$ & $0.84 * * *$ & -0.20 \\
\hline Medium & & & $0.52 * * *$ & -0.14 & $0.49 * * *$ & -0.12 \\
\hline Private & & & & & $0.53^{*}$ & -0.18 \\
\hline Foreign & & & & & $0.48^{*}$ & -0.08 \\
\hline athrho & \multicolumn{2}{|c|}{$-1.48 * * *$} & \multicolumn{2}{|c|}{$-1.54 * * *$} & \multicolumn{2}{|c|}{$-1.56^{* * *}$} \\
\hline $\begin{array}{l}\chi^{2} \text { (Wald test of } \\
\text { exogeneity) }\end{array}$ & \multicolumn{2}{|c|}{$49.84 * * *$} & \multicolumn{2}{|c|}{$71.21 * * *$} & \multicolumn{2}{|c|}{$78.56^{* * *}$} \\
\hline
\end{tabular}

Hypothesis 1 proposes that there is positive relationship between cooperative intention and cooperative decision and fully mediates the effect of all other antecedents. The results across all cases are significant. Therefore, hypothesis 1 is supported. Related to the impact of expectation from inter-firm cooperation on cooperative intention, hypothesis 2 predicts that expectation from inter-firm cooperation has positive relationship with cooperative intention. The coefficient has positive sign and is highly. These results provide support for 
hypothesis 2. Moreover, expectation from inter-firm cooperation seems to be the most influence on cooperation intention, as indicated by highest coefficient among the antecedents of cooperative intention (see Table 2). This finding reveals the importance of this element in explaining behaviours across wide range of theories (Armitage \& Conner, 2001; Bagozzi \& Warshaw, 1990; Carr \& Sequeira, 2007).

Hypothesis 3 and 4 state that attitude toward inter-firm cooperation and subjective norms are positively associated with cooperative intention. As indicated in Table 2 (columns 2), these hypotheses are supported. This result is consistent with the previous research findings (Ajzen, 1991; Armitage \& Coner, 2001).

Hypothesis 5 predicts that perceived control is positively related to cooperative intention. It is important to note that this variable is highly significant $(\mathrm{p}<0.05)$. The result of the IV probit regression shows that hypothesis 5 is supported. Hypothesis 6 expect the positive linkage to cooperation intention among firms. The similarities between partners has a positive influence on the probability of strong inter-firm cooperation. Hypothesis 6 is thus empirically confirmed.

With the purpose of validating robustness of the results, the study adds a long series of control variables to predict cooperative behaviour in two other models ( 2 and 3 ) in Table 2. Case 2 examines the effect of company size on behaviour while Case 3 looks for the impact of ownership differences. The VIFs of independent variables in all regression models range from 1.16 to 1.98 , suggesting that the problem of multicollinearity does not exist (Hair et al., 2009).

Importantly, the inclusion of the additional controls does not alter the patterns of the results. On the one hand, the sign of all coefficients still remain in all cases. On the other hand, the values of these coefficients do not change much. For instance, coefficients represented for cooperative intention value at $0.92,0.93$, and 1.01 in Case 1, Case 2, and Case 3 respectively in Table 2. Further, the values of robust standard errors of all variables seem to be same in all regressions. These findings confirm the robustness of the results.

Overall, all hypotheses receive strongly statistical supports (all coefficients are positive and significant across Case 1 through Case 3). In line with TPB and TAM, these results suggest that cooperative intention fully mediates the relationships of five key indicators (expectation from inter-firm cooperation, attitude toward inter-firm cooperation, subjective norms, perceived control and similarities between partners) with cooperation. Cooperative intention plays a critical role as indicated by the continued strength of four antecedent variables. Moreover, consistent with Arku (2002) and Nguyen (2011), the study discovers that the small and medium enterprises are more likely to engage in inter-firm cooperation. This finding reflects that these companies are calling for resources from outside. It seems to be true that some of them are going to expand business activities. On the other hand, the results also revealed the fact that similarities between partners will facilitate inter-firm cooperation due to reduce free riding among partners. This result also supports for the findings of Saxton (1997).

\section{Discussions and Limitations}

\subsection{Theoretical Implications}

Previous studies have applied the theory of planned behaviour and technology acceptance model to examine the impact of key indicators in creation of behavioural intention. Besides, the researchers have used the commitment trust theory (Morgan \& Hunt, 1994) widely in examining consumer behaviours. However, no research has been devoted for examining inter-firm cooperation from combining these theories. By filling this gap research, the study reveals several important notes to the theory.

Firstly, the empirical study contributes to existing literature by combining not only a large number of these constructs, but links them in a comprehensive way to investigate inter-firm cooperation. Most hypotheses receive support. Importantly, expectation from inter-firm cooperation plays the most powerful role in cooperative intention among the constructs. Inter-firm cooperation, which looks slightly different from human behaviour, seeks for expected outcomes in inter-firm relationship. Secondly, in the effort of testing the theory of planned behaviour in organizational context, this study supplements the knowledge of inter-firm theory. The attitude toward cooperation plays its predicted role in inter-firm relationships, "preferably" managerial predisposition toward cooperation associated with an increased likelihood of inter-firm cooperation. The attitude toward cooperation also helps us in understanding the reason why trust has been key mediating variable in commitment-trust theory (Morgan \& Hunt, 1994). This finding somewhat casts doubt on the results of other studies in TPB, which have neglected the human effect on behaviours (e.g. Thompson \& Panayiotopoulos, 1999; Tonglet et al., 2004). Thirdly, this research attempts to provide insights into the relationship between social pressures and cooperative intention. According to empirical results, subjective norms have a positive influence on managers involving in inter-firm relationships. Vietnamese managers who perceive social pressure from 
referents and other firms toward cooperation show higher cooperative intentions. From the view of cultural dimensions proposed by Hofstede (2001), these findings are consistent with collectivistic cultures like Chile and Vietnam in which citizens in these countries emphasize the co-dependency between individuals and their groups (Nasco et al., 2008; Tran et al., 2009). Fourthly, perceived control contributes to facilitate cooperation decision indirectly through cooperative intention. Rules of the game are important for regulating behaviour and limiting uncertainties and occasions for opportunistic behaviour like inter-firm cooperation. Lastly, similarities between partners do affect inter-firm relationship. The more strategic fit and organizational fit, the higher possibility for inter-firm cooperation. Enterprise will seek to cooperate with the partner similar in some context.

\subsection{Managerial Implications}

The findings of this research suggest several implications for companies. Firstly, in order to make inter-firm cooperation successfully, the managers have to take all main determinants into considerations especially with the expected outcome of the relationship. Secondly, company can enhance the chance for inter-firm cooperation not only by assigning the high attitude toward cooperation's executive to the relationship but also by seeking homogenous enterprises in some aspects. Thirdly, company can use social pressure to shape behaviour of its partner in the relationship.

\section{References}

Ajzen, I. (1991). The theory of planned behavior. Organizational Behavior and Human Decision Processes, 50, 179-211. http://dx.doi.org/10.1016/0749-5978(91)90020-T

Anderson, J. C., \& Narus, J. A. (1990). Model of distributor firm and manufacturer firm working partnerships. Journal of Marketing, 54, 42-58. http://dx.doi.org/10.2307/1252172

Arku, G. (2002). Collaboration in industry: Empirical findings among small electronics manufacturing firms in $\begin{array}{llll}\text { the } & \text { greater } & \text { Toronto } & \text { area. GeoJournal, }\end{array}$ http://dx.doi.org/10.1023/B:GEJO.0000007358.00395.0d

Armitage, C. J., \& Conner, M. (2001). Efficacy of the theory of planned behavior: A meta-analytic review. British Journal of Social Psychology, 40(4), 471-499. http://dx.doi.org/10.1348/014466601164939

Armstrong, J. S., \& Overton, T. S. (1977). Estimating nonresponse bias in mail surveys. Journal of Marketing Research, 14(3), 396-402. http://dx.doi.org/10.2307/3150783

Atkinson, J. W. (1964). An introduction to motivation. Princeton, NJ: Van Nostrand.

Bagozzi, R. P., \& Warshaw, P. R. (1990). Trying to consume. Journal of Consumer Research, 17(2), 127-140. http://dx.doi.org/10.1086/208543

Bandura, A. (1997). Self-efficacy: The exercise of control. New York: W. H. Freeman.

Beritelli, P. (2011). Cooperation among prominent actors in a tourist destination. Annals of Tourism Research, 38(2), 607-629. http://dx.doi.org/10.1016/j.annals.2010.11.015

Cameron, A. C., \& Trivedi, P. K. (2009). Microeconometrics using STATA. A Stata Press Publication.

Carr, J. C. \& Sequeira, J. M. (2007). Prior family business exposure as intergenerational influence and entrepreneurial intent: A theory of planned behavior approach. Journal of Business Research, 60, 1090-1098. http://dx.doi.org/10.1016/j.jbusres.2006.12.016

Chassagnon, V. (2014). Consummate cooperation in the network-firm: Theoretical insights and empirical findings. European Management Journal, 32(2), 260-274. http://dx.doi.org/10.1016/j.emj.2013.01.002

Chen, F., Curran, P. J., Bollen, K. A., Kirby, J., \& Paxton, P. (2008). An empirical evaluation of the use of fixed cutoff points in RMSEA test statistic in structural equation models. Sociological Methods \& Research, 36(4), 462-494. http://dx.doi.org/10.1177/0049124108314720

Chow, P. T., Cheung, S. O., \& Chan, K. Y. (2012). Trust-building in construction contracting: Mechanism and

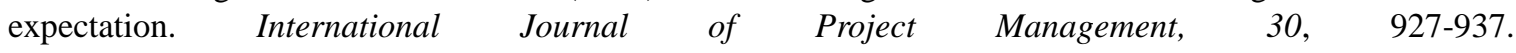
http://dx.doi.org/10.1016/j.ijproman.2012.03.002

Close, A. G., \& Kukar-Kinney, M. (2010). Beyond buying: Motivations behind consumers' online shopping cart use. Journal of Business Research, 63(9-10), 986-992. http://dx.doi.org/10.1016/j.jbusres.2009.01.022

Conner, M., \& McMillan, B. (1999). Interaction effects in the theory of planned behaviour: Studying cannabis use. British Journal of Social Psychology, 38(2), 195-222. http://dx.doi.org/10.1348/014466699164121

Davis, F. D. (1986). A technology acceptance model for empirically testing new end-user information systems: 
Theory and results. (Doctoral dissertation, Sloan School of Management, Massachusetts Institute of Technology).

Davis, F. D., Bagozzi, R. P., \& Warshaw, P. R. (1989). User acceptance of computer technology: A comparison of two theoretical models. Management Science, 35(8), 982-1003. http://dx.doi.org/10.1287/mnsc.35.8.982

De Cannière, M. H., De Pelsmacker, P., \& Geuens, M. (2009). Relationship quality and the theory of planned behavior models of behavioral intentions and purchase behavior. Journal of Business Research, 62(1), 82-92. http://dx.doi.org/10.1016/j.jbusres.2008.01.001

Deci, E. L., \& Ryan, R. M. (1987). The support of autonomy and the control of behavior. Journal of Personality and Social Psychology, 53(6), 1024-1037. http://dx.doi.org/10.1037/0022-3514.53.6.1024

Durvasula, S., Andrews, J. C., Lysonski, S., \& Netemeyer, R. G. (1993). Assessing the cross-national applicability of consumer behavior models: A model of attitude toward advertising in general. Journal of Consumer Research, 19(4), 626-636. http://dx.doi.org/10.1086/209327

Fang, E., Palmatier, R. W., Scheer, L. K., \& Li, N. (2008). Trust at different organizational levels. Journal of Marketing, 72(2), 80-98. http://dx.doi.org/10.1509/jmkg.72.2.80

Fishbein, M., \& Ajzen, I. (1975). Belief, attitude, intention and behavior: an introduction to theory and research. Addision-Wesley Addison-Wesley series in social psychology.

Fornell, C., \& Larcker, D. F. (1981). Structural equation models with unobservable variables and measurement error. Journal of Marketing Research, 18, 39-50. http://dx.doi.org/10.2307/3150980

Fritsch, M. (2003). Does R\&D cooperation behavior differ between regions? Industry and Innovation, 10(1), 25-39. http://dx.doi.org/10.1080/1366271032000068087

Hair, J. F., Black, W. C., Babin, B. J., \& Anderson, R. E. (2009). Multivariate data analysis (7th ed.). Prentice Hall.

Heikki, K., Heikki, L., Matti, L., \& Chanaka, J. (2008). Exploring gender influence on customer's intention to engage permission-based mobile marketing. Electronic Markets, 18(3), 242-259. http://dx.doi.org/10.1080/10196780802265793

Hill, M., Mann, L., \& Wearing, A. J. (1996). The effects of attitude, subjective norm and self-efficacy on intention to benchmark: A comparison between managers with experience and no experience in $\begin{array}{lllll}\text { benchmarking. Journal of } & \text { Organizational Behavior, 17(4), }\end{array}$ http://dx.doi.org/10.1002/(SICI)1099-1379(199607)

Hofstede, G. (2001). Culture's consequences: Comparing values, behaviors, institutions, and organizations across nations (2nd ed.). Thousand Oaks, CA: Sage.

Huybers. T., \& Bennett. J. (2003). Inter-firm cooperation at nature-based tourism destinations. Journal of Socio-Economics, 32(5), 571-587. http://dx.doi.org/10.1016/j.socec.2003.08.011

Kennedy, M. S., Ferrell, L. K., \& LeClair, D. T. (2001). Consumer's trust of salesperson and manufacturer: An $\begin{array}{lllll}\text { empirical study. Journal of Business Research, 51(1), } & \text { 73-86. }\end{array}$ http://dx.doi.org/10.1016/S0148-2963(99)00039-9

Koufaris, M. (2002). Applying the technology acceptance model and flow theory to online consumer behavior. Information Systems Research, 13(2), 205-223. http://dx.doi.org/10.1287/isre.13.2.205.83

Krueger, N. F., Reilly, M. D., \& Carsrud, A. L. (2000). Competing models of entrepreneurial intentions. Journal of Business Venturing, 15(5-6), 411-432. http://dx.doi.org/10.1016/S0883-9026(98)00033-0

Kulviwat, S., Bruner II, G. C., \& Al-Shuridah, O. (2009). The role of social influence on adoption of high tech innovations: The moderating effect of public/private consumption. Journal of Business Research, 62(7), 706-712. http://dx.doi.org/10.1016/j.jbusres.2007.04.014

Kumar, V., Bohling, T. R., \& Ladda, R. N. (2003). Antecedents and consequences of relationship intention: Implications for transaction and relationship marketing. Industrial Marketing Management, 32(8), 667-676. http://dx.doi.org/10.1016/j.indmarman.2003.06.007

Lancastre, A., \& Lages, L. F. (2006). The relationship between buyer and B2B e-marketplace: Cooperation determinants in a electronic market context. Industrial Marketing Management, 35(6), 774-789. http://dx.doi.org/10.1016/j.indmarman.2005.03.011

Ludin, M. (2007). Explaining cooperation: How resource interdependence, goal congruence, and trust affect 
joint actions in policy implementation. Journal of Public Administration Research and Theory, 17(4), 651-672. http://dx.doi.org/10.1093/jopart/mul025

Lui, S, S., Ngo, H. Y., \& Hon, A. H. Y. (2006). Coercive strategy in interfirm cooperation: Mediating roles of interpersonal and interorganizational trust. Journal of Business Research, 59(4), 466-474. http://dx.doi.org/10.1016/j.jbusres.2005.09.001

Manstead, A. S. R., \& Van Eekelen, S. A. M. (1998). Distinguishing between perceived behavioral control and self-efficacy in the domain of academic achievement intentions and behaviors. Journal of Applied Social Psychology, 28(15), 1375-1392. http://dx.doi.org/10.1111/j.1559-1816.1998.tb01682.x

Morgan, R. M., \& Hunt, S. D. (1994). The commitment-trust theory of relationship marketing. Journal of Marketing, 58(3), 20-38. http://dx.doi.org/10.2307/1252308

Nasco, S. A., Toledo, E. G., \& Mykytyn, P. P. Jr. (2008). Predicting electronic commerce adoption in Chilean SMEs. Journal of Business Research, 61(6), 697-705. http://dx.doi.org/10.1016/j.jbusres.2007.06.047

Netemeyer, R. G., Andrews, J. C., \& Durvasnia, S. (1993). A comparison of three behavioral intention models: The case of Valentine's Day gift-giving. Advances in Consumer Research, 20, 135-141.

Nguyen, N. P. (2011). Applying theory of reasoned action to explain inter-firm cooperation: Empirical evidence from Vietnamese enterprises. International Journal of Management \& Information Systems, 15, 61-81.

Nguyen, T. V., \& Rose, J. (2009). Building Trust-Evidence from Vietnamese Entrepreneurs. Journal of Business Venturing, 24, 165-182. http://dx.doi.org/10.1016/j.jbusvent.2008.03.004

Nysveen, H., Pedersen, P. E., \& Thorbjernsen, H. (2005). Intentions to use mobile services: Antecedents and cross-service. Journal of the Academy of Marketing Science, 33(3), 330-346. $\mathrm{http}: / / \mathrm{dx}$.doi.org/10.1177/0092070305276149

Okamuro, H. (2007). Determinants of successful R\&D cooperation in Japanese small business: The impact of organizational and contractual characteristics. Research Policy, 36(10), 1529-1544. http://dx.doi.org/10.1016/j.respol.2006.12.008

Pittino, D., \& Visintin, F. (2011). The propensity toward inter-organizational cooperation in small and medium-sized family businesses. Journal of Family Business Strategy, 2, 57-68. http://dx.doi.org/10.1016/j.jfbs.2011.03.005

Podsakoff, P. M., MacKenzie, S. B., Lee, J., \& Podsakoff, N. P. (2003). Common method biases in behavioral research: A critical review of the literature and recommended remedies. Journal of Applied Psychology, 88(5), 879-903. http://dx.doi.org/10.1037/0021-9010.88.5.879

Rivers, D., \& Vuong, Q. H. (1988). Limited information estimators and exogeneity tests for simultaneous probit models. Journal of Econometrics, 39(3), 347-366. http://dx.doi.org/10.1016/0304-4076(88)90063-2

Saxton, T. (1997). The effects of partner and relationship characteristics on alliance outcomes. Academy of Management Journal, 40(2), 443-461. http://dx.doi.org/10.2307/256890

Schermerhorn, J. R. Jr. (1975). Determinant of interorganizational cooperation. Academy of Management Journal, 18(4), 846-856. http://dx.doi.org/10.2307/255382

Schumacker, R. E., \& Lomax, R. G. (2004). A beginner's guide to structural equation modeling (2nd ed.). Mahwah, NJ: Lawrence Erlbaum Associates.

Sheppard, B. H., Hartwick, J., \& Warshaw, P. R. (1988). The theory of reasoned action: A meta-analysis of part research with recommendation for modifications and future research. Journal of Consumer Research, 15(3), 325-343. http://dx.doi.org/10.1086/209170

Teece, D. (1977). Technology transfer by multinational firms: The resource cost of international technological transfer. Economic Journal, 87, 242-261. http://dx.doi.org/10.2307/2232084

Terry, D. J., \& O’Leary, J. E. (1995). The theory of planned behavior: The effects of perceived behavioral control and self-efficacy. British Journal of Social Psychology, 34(2), 199-220. http://dx.doi.org/10.1111/j.2044-8309.1995.tb01058.x

Thøgersen, J. (2008). Social norms and cooperation in real-life social dilemas. Journal of Economic Psychology, 29(4), 458-472. http://dx.doi.org/10.1016/j.joep.2007.12.004

Thompson, K. E., \& Panayiotopoulos, P. (1999). Predicting behavioural intention in a small business context. Journal of Marketing Practice: Applied Marketing Science, 5(3), 89-96. 
http://dx.doi.org/10.1108/EUM0000000004564

Tonglet, M., Phillips, P. S., \& Read, A. D. (2004). Using the theory of planned behaviour to investigate the determinants of recycling behaviour: A case study from Brixworth, UK. Resources, Conservation and Recycling, 41(3), 191-214. http://dx.doi.org/10.1016/j.resconrec.2003.11.001

Tran, T. B., Grafton, R. Q., \& Kompas, T. (2009). Institutions matter: The case of Vietnam. The Journal of Socio-Economics, 38(1), 1-12. http://dx.doi.org/10.1016/j.socec.2008.05.012

Van Bruggen, G. H., Lilien, G. L., \& Kacker, M. (2002). Informants in organizational marketing research: Why use multiple informants and how to aggregate responses. Journal of Marketing Research, 39(4), 469-478. http://dx.doi.org/10.1509/jmkr.39.4.469.19117

Venkatesh, V. (2000). Determinant of perceived ease of use: Integrating control, intrinsic motivation, and emotion into the technology acceptance model. Information Systems Research, 11(4), $342-365$. http://dx.doi.org/10.1287/isre.11.4.342.11872

Zhang, B., \& Wang, Z. (2014). Inter-firm collaborations on carbon emission reduction within industrial chains in China: Practices, drivers and effects on firm's performances. Energy Economics, 42, 115-131. http://dx.doi.org/10.1016/j.eneco.2013.12.006

\section{Appendix}

\section{Means, standard deviations, and correlations among variables}

\begin{tabular}{|c|c|c|c|c|c|c|c|c|c|c|c|c|c|}
\hline Variables & Means & S.D. & 1 & 2 & 3 & 4 & 5 & 6 & 7 & 8 & 9 & 10 & 11 \\
\hline 1. Cooperation & 0.74 & 0.44 & 1.00 & & & & & & & & & & \\
\hline 2. Intention & 4.93 & 1.32 & $0.59 * *$ & 1.00 & & & & & & & & & \\
\hline 3. Expectation & 4.52 & 1.24 & $0.67 * *$ & $0.55 * *$ & 1.00 & & & & & & & & \\
\hline 4. Attitude & 3.11 & 0.92 & $0.62 * *$ & $0.42 * *$ & $0.61 * *$ & 1.00 & & & & & & & \\
\hline 5. Subjective & 1.58 & 0.67 & $0.36^{* *}$ & $0.33 * *$ & $0.19^{* *}$ & $0.17 * *$ & 1.00 & & & & & & \\
\hline 6. Perceived & 4.79 & 1.11 & $0.41^{* *}$ & $0.21 * *$ & 0.23 & $0.09 *$ & 0.14 & 1.00 & & & & & \\
\hline 7. Similarities & 3.19 & 1.74 & $0.51^{* *}$ & $0.39 * *$ & $0.18 *$ & $0.27 * *$ & 0.02 & $0.34^{*}$ & 1.00 & & & & \\
\hline 8. Small & 0.69 & 0.48 & 0.02 & 0.17 & 0.12 & -0.08 & $-0.24 *$ & 0.03 & 0.02 & 1.00 & & & \\
\hline 9. Medium & 0.20 & 0.40 & $0.15^{*}$ & 0.14 & 0.16 & 0.08 & 0.17 & 0.08 & $0.24 *$ & -0.11 & 1.00 & & \\
\hline 10. Private & 0.62 & 0.51 & $0.07^{*}$ & 0.03 & 0.14 & 0.06 & -0.01 & 0.03 & 0.07 & -0.04 & 0.08 & 1.00 & \\
\hline 11. Foreign & 0.26 & 0.38 & $0.28 * *$ & 0.07 & 0.01 & 0.09 & 0.02 & 0.14 & 0.06 & 0.06 & $0.31 * *$ & -0.05 & 1.00 \\
\hline
\end{tabular}

Note. Correlation is significant at $* * \mathrm{p}<0.01, * \mathrm{p}<0.05$ (2-tailed).

\section{Copyrights}

Copyright for this article is retained by the author(s), with first publication rights granted to the journal.

This is an open-access article distributed under the terms and conditions of the Creative Commons Attribution license (http://creativecommons.org/licenses/by/3.0/). 